\title{
Mast cell chymase promotes hypertrophic scar fibroblast proliferation and collagen synthesis by activating TGF-ß1/Smads signaling pathway
}

\author{
HONGMING CHEN, YANWEN XU, GUANBIN YANG, QIANQIAN ZHANG, \\ XUN HUANG, LIMING YU and XIANGLIN DONG \\ Department of Burns and Plastic Surgery, The First Affiliated Hospital of Xinjiang Medical University, \\ Urumqi, Xinjiang Uyghur Autonomous Region 830011, P.R. China
}

Received September 1, 2016; Accepted May 11, 2017

DOI: $10.3892 /$ etm.2017.5082

\begin{abstract}
The present study assessed the existence of mast cell chymase in hypertrophic scars and determined whether chymase promotes fibrosis via the transforming growth factor (TGF)- $\beta 1 /$ Smads signaling pathway. Five patients with hypertrophic scars and another five patients subjected to repair and reconstruction of other tissue defects were included in the present study. To detect the existence of mast cells and mast cell chymase in hypertrophic scars, immunohistochemistry was employed. To test the effect of chymase on TGF- $\beta 1$, angiotensin, and type I and III collagen mRNA expression in isolated hypertrophic scar fibroblasts in vitro, reverse-transcription quantitative PCR was performed. To investigate how chymase affects TGF- $\beta 1$, phosphorylated (P)-Smad2/3 as well as Smad4 and Smad7 protein expression, western blot analysis was used. Mast cell chymase was identified to promote the mRNA expression of TGF- $\beta 1$, angiotensin, and type I and III collagen in hypertrophic scar fibroblasts in a time- and dose-dependent manner. Furthermore, treatment with $60 \mathrm{ng} / \mathrm{ml}$ mast cell chymase for $12 \mathrm{~h}$ led to the upregulation of TGF- $\beta 1, \mathrm{P}-\mathrm{Smad} 2 / 3, \mathrm{Smad} 4$ and $\mathrm{Smad} 7$ in hypertrophic scar fibroblasts. The present study demonstrated that mast cells and chymase are present in hypertrophic scars, and chymase promotes hypertrophic scar fibroblast proliferation and collagen synthesis by activating the TGF- $\beta 1 / \mathrm{Smads}$ signaling pathway.
\end{abstract}

Correspondence to: Professor Xianglin Dong, Department of Burns and Plastic Surgery, The First Affiliated Hospital of Xinjiang Medical University, 137 South Liyushan Road, Urumqi, Xinjiang Uyghur Autonomous Region 830011, P.R. China

E-mail: dongx181@sina.com

Key words: mast cell chymase, hypertrophic scar fibroblast, TGF- $\beta 1 /$ Smads signaling pathway

\section{Introduction}

Hypertrophic scars are a common type of post-traumatic tissue repair abnormality (1). Hypertrophic scars formed during wound healing are mainly characterized by the overexpression of multiple fibrogenic factors, as well as excessive synthesis and reduced degradation of extracellular matrix, such as collagen (2). However, their pathogenesis has remained to be fully elucidated.

Chymase secreted by mast cells is a type of serine protease and its release activates transforming growth factor (TGF)- $\beta 1$ via paracellular secretion stimulation and fibrinolysin (3-5). A previous study demonstrated that chymase has a potential role in tissue fibrosis (6). In addition, chymase secreted by mast cells was found to promote the release of TGF- $\beta 1$ in the extracellular matrix of human epithelial and endothelial cells (7). It was also reported that chymase facilitates cell proliferation via the TGF- $\beta 1$ signaling pathway (8).

The TGF- $\beta 1 /$ Smads signaling pathway has been demonstrated to have important roles in the formation of hypertrophic scars (9). TGF- $\beta 1$ stimulates the proliferation of fibroblasts and the production of collagen, and inhibits matrix degradation, finally leading to the formation of hypertrophic scars (10). Inhibition of the TGF- $\beta 1 /$ Smads signaling pathway was reported to suppress the formation of hypertrophic scars (11). TGF- $\beta$ is a cytokine that activates the intracellular Smad signaling pathway and has a key role in promoting wound healing and tissue remodeling after repair (10). Smad proteins are among the most important intracellular signal transduction proteins downstream of the TGF- $\beta$ superfamily (12-14). Mast cells exist in hypertrophic scars and have a role in their formation (15). However, it has remained elusive whether chymase secreted by mast cells activates the Smad signaling pathway via TGF- $\beta 1$ in hypertrophic scars. In the present study, the role of mast cell chymase in the in hypertrophic scar fibroblast formation via the TGF- $\beta 1 /$ Smads signaling pathway was investigated.

\section{Materials and methods}

Subjects. A total of 5 patients with hypertrophic scars and an additional 5 patients subjected to repair and reconstruction of 
other tissue defects at the Department of Burns and Plastic Surgery, the First Affiliated Hospital of Xinjiang Medical University between May 2014 and May 2015 were included in the present study. The subjects were otherwise healthy and none of them had received any anti-scar treatment within two years or had any systemic disease. A piece of tissue was cut from each hypertrophic scar for histochemical examination in order to further confirm the validity of the clinical diagnosis (Table I). All procedures were approved by the Ethics Committee of Xinjiang Medical University (Urumqi, China). Written informed consent was obtained from all subjects or their families.

Cells. Hypertrophic scar samples were washed with PBS containing ampicillin and streptomycin (HyClone; GE Healthcare, Little Chalfont, UK), and epithelial and subcutaneous adipose tissues were removed. The samples were cut into $1-\mathrm{mm}^{3}$ pieces and cultured in low-glucose Dulbecco's modified Eagle's medium supplemented with $10 \%$ fetal bovine serum (both from HyClone; GE Healthcare) at $37^{\circ} \mathrm{C}$ under $5 \% \mathrm{CO}_{2}$. The medium was refreshed twice a week and finally, hypertrophic scar fibroblasts were obtained. When the fibroblasts reached $70-80 \%$ confluence, $0.25 \%$ trypsin (HyClone; GE Healthcare, Logan, UT, USA) was used to digest the cells, which were then collected split for further culture. The medium was refreshed every two days, and the growth speed and morphology of the fibroblasts were observed under an inverted phase contrast microscope. The cells at passage 3-6 were used for the experiments.

Immunohistochemical staining. Sample tissues from each group (hypertrophic scar and normal skin) were enclosed with pathological filter paper, fixed immediately with $10 \%$ buffered formalin at room temperature overnight, processed through graded alcohols and xylene, embedded in paraffin, and sectioned at $5-\mu \mathrm{m}$ thickness (3 replicates for each specimen). Mast cells and mast cell chymase were immunohistochemically stained using polyclonal rabbit anti-human CD117 (1:500; cat no. LS-C20514; c-Kit; LifeSpan BioSciences, Inc., Seattle, WA, USA) antibody and polyclonal mouse anti-chymase antibody (1:500; cat no. k1086Bo01; Gene Company Ltd., Shanghai, China), respectively, and incubated at $4^{\circ} \mathrm{C}$ overnight. Samples were subsequently incubated with horseradish peroxidase-conjugated anti-rabbit secondary antibody (1:1,000; cat no. GK500705; Dako; Agilent Technologies, Inc., Santa Clara, $\mathrm{CA}, \mathrm{USA}$ ) at $37^{\circ} \mathrm{C}$ for $30 \mathrm{~min}$. Positive expression of CD117 and chymase was indicated by brown staining of cell membrane and cytoplasm. As a negative control, PBS was used instead of primary antibodies.

Reverse transcription-quantitative polymerase chain reaction $(R T-q P C R)$. Hypertrophic scar fibroblasts were treated with different concentrations $(0,15,30,60$ and $120 \mathrm{ng} / \mathrm{ml})$ of chymase (cat no. C8118; Sigma-Aldrich; Merck KGaA, Darmstadt, Germany) for 6, 12 and $24 \mathrm{~h}$ prior to analysis. Total RNA was extracted from the cells at the first passage using TRIzol reagent (Thermo Fisher Scientific, Inc., Waltham, MA, USA). Complementary DNA was obtained by RT using the TIANScript RT kit (Tiangen, Beijing, China) at $37^{\circ} \mathrm{C}$ for $15 \mathrm{~min}$, followed by an enzyme inactivation reaction at $98^{\circ} \mathrm{C}$ for $5 \mathrm{~min}$. The primers were as follows: TGF- $\beta 1$ (158 bp), 5'-ACACCAACTATTGCT
Table I. Sources of hypertrophic scars.

\begin{tabular}{lcllcl}
\hline Group & $\begin{array}{c}\text { Age } \\
\text { (years) }\end{array}$ & Gender & $\begin{array}{c}\text { Scar } \\
\text { location }\end{array}$ & $\begin{array}{c}\text { Family } \\
\text { history }\end{array}$ & $\begin{array}{c}\text { Course } \\
\text { of disease }\end{array}$ \\
\hline HSFs & 24 & Female & Chest & - & 9 months \\
& 31 & Female & Neck & + & 25 months \\
& 26 & Female & Upper arm & - & 10 months \\
& 29 & Female & Chest & + & 8 months \\
& 21 & Female & Ear & - & 14 months \\
NFs & 20 & Male & Abdomen & - & 1 year \\
& 25 & Female & Abdomen & - & 2 years \\
& 27 & Female & Shank & - & 6 months \\
& 41 & Female & Forearm & - & 3 years \\
& 23 & Female & Forearm & - & 8 months
\end{tabular}

Family history refers to a family history of pathological scars, including keloid and hypertrophic scars. HSFs, hypertrophic scar fibroblasts; NFs, normal fibroblasts.

TCAG-3' (forward) and 5'-TGTCCAGGCTCCAAATG-3' (reverse); collagen type I, $\alpha 1$ (COL1A1; 147 bp), 5'-CCCGGG TTTCAGAGAGACAACTTC-3' (forward) and 5'-TCCACA TGCTTTATTCCAGCAATC-3' (reverse); COL3A1 (244 bp), 5'-CTTCTCTCCAGCCGAGCTTC-3' (forward) and 5'-GTAGTCTCACAGCCTTGCGT-3' (reverse); angiotensin (197 bp), 5'-CAAGGTGGAGGGTCTCAC-3' (forward) and 5'-CTGATGCGGTCATTGCTC-3' (reverse); $\beta$-actin (187 bp), 5'-TGGCACCCACAATGA A-3' (forward) and 5'-CTAAGT CATAGTCCGCCTAGAAGCA-3' (reverse). PCR was performed on a thermo cycler (Bio-Rad Laboratories, Inc., Hercules, CA, USA) using a QuantiFast SYBR-Green PCR kit (Qiagen, Hilden, Germany) according to the manufacturer's manual. The PCR reaction protocol was as follows: Initial denaturation at $95^{\circ} \mathrm{C}$ for $5 \mathrm{~min}$, followed by 39 cycles of $95^{\circ} \mathrm{C}$ for $10 \mathrm{sec}$ and $60^{\circ} \mathrm{C}$ for $30 \mathrm{sec}$. Quantitative measurements were performed using the $2^{-\Delta \Delta \mathrm{Cq}}$ method (16), and $\beta$-actin was used as an internal reference. Each sample was measured in triplicate.

Western blot analysis. After washing with ice-cold PBS twice, the 4th passage of the cells were lysed using pre-cooled radioimmunoprecipitation assay lysis buffer and phenylmethanesulfonyl fluoride (both from Thermo Fisher Scientific, Inc.) for $50 \mathrm{~min}$ on ice. The mixture was then centrifuged at $12,000 \mathrm{x} \mathrm{g}$ and $4^{\circ} \mathrm{C}$ for $5 \mathrm{~min}$. The supernatant was used to determine the protein concentration by using a bicinchoninic acid protein concentration determination kit (BioTeke Corp., Beijing, China). After denaturation, the samples were subjected to $12 \%$ SDS-PAGE. The resolved proteins were transferred to polyvinylidene difluoride membranes (EMD Millipore, Billerica, MA, USA) on ice and blocked with 5\% skimmed milk at room temperature for $1 \mathrm{~h}$. The membranes were then incubated with TGF- $\beta 1$ antibody (1:300 dilution; cat no. sc-146), Smad7 (1:300 dilution; cat no. sc-11392), Smad4 (1:300 dilution; cat no. sc-7966), GAPDH (1:300 dilution; cat no. sc-25778) (all from Santa Cruz Biotechnology, Inc., Dallas, TX, USA) or p-Smad2/3 (1:1,000 dilution; cat no. 8828s; Cell Signaling Technology, Inc., Beverly, MA, 


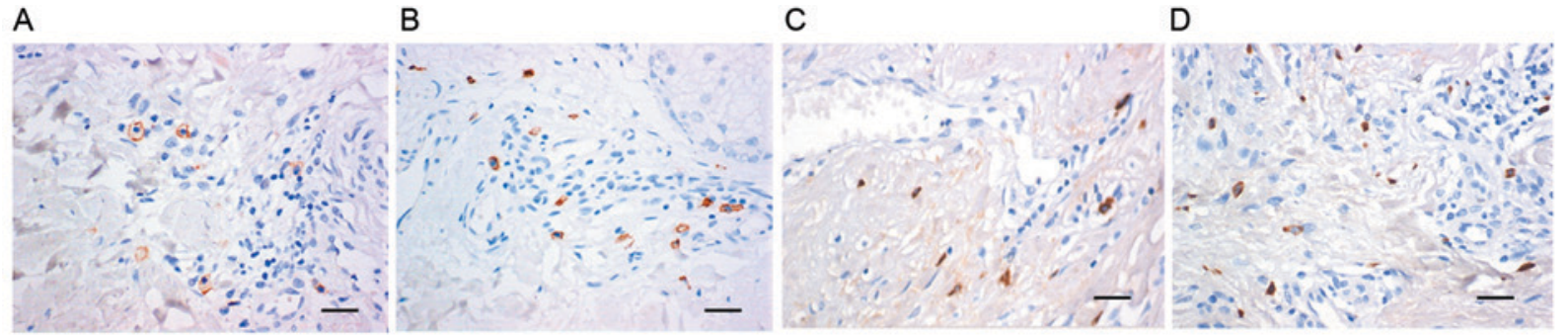

Figure 1. Immunohistochemical staining of mast cells of (A) normal skin and (B) hypertrophic scar tissue with anti-CD117 antibodies. Staining of (C) normal skin and (D) hypertrophic scar tissue for mast cell chymase (magnification, $\mathrm{x} 400$; scale bar, $50 \mu \mathrm{m}$ ).

A

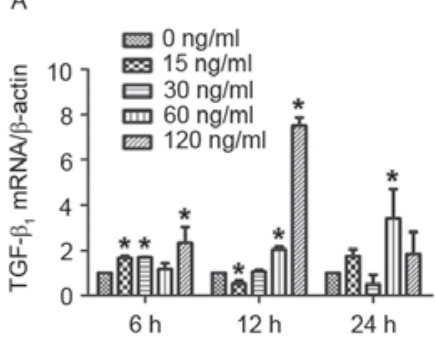

B

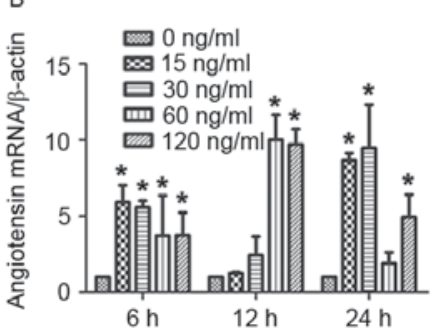

C

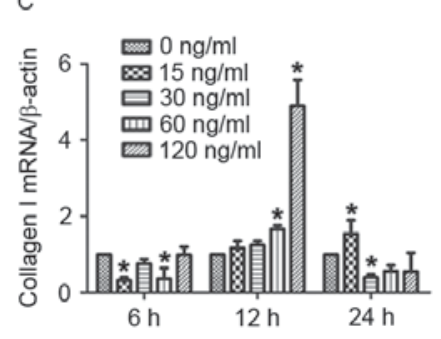

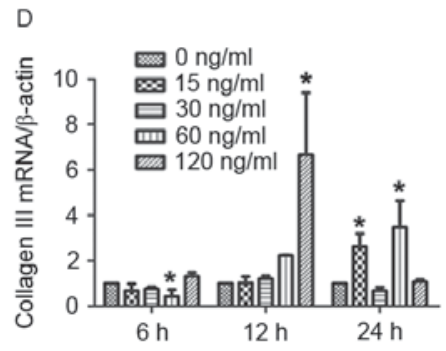

Figure 2. Effect of chymase on the mRNA expression of TGF- $\beta 1$, angiotensin, and type I and III collagen in hypertrophic scar fibroblasts. Reverse-transcription quantitative polymerase chain reaction analysis was used to measure the mRNA expression after treatment with different concentrations of chymase $(0,15$, 30,60 and $120 \mathrm{ng} / \mathrm{ml}$ ) for 6,12 or $24 \mathrm{~h}$. mRNA expression of (A) TGF- $\beta 1$, (B) angiotensin, (C) type I collagen and (D) type III collagen relative to $\beta$-actin. All experiments were performed in triplicate. Values are expressed as the mean \pm standard deviation. ${ }^{*} \mathrm{P}<0.05$ compared with control $(0 \mathrm{ng} / \mathrm{ml}$ chymase). TGF, transforming growth factor.

USA) at $4^{\circ} \mathrm{C}$ overnight. After washing with Tris-buffered saline with Tween-20 for $2 \mathrm{~h}$, the membranes were incubated with horseradish peroxidase-conjugated secondary antibody (1:1,000 dilution; cat no. 77054s; Cell Signaling Technology, Inc.) at room temperature for $2 \mathrm{~h}$. The membrane was then developed using an enhanced chemiluminescence detection kit (Sigma-Aldrich; Merck KGaA) for imaging on X-ray film (ChemiDoc MP; Bio-Rad Laboratories, Inc.). Band intensity was acquired and analyzed using Quantity One software (version 4.6.2; Bio-Rad Laboratories, Inc.).

Statistical analysis. The results were analyzed using SPSS 17.0 statistical software (SPSS, Inc., Chicago, IL, USA). Values are expressed as the mean \pm standard deviation. Differences between groups were analyzed using general linear single-factor analysis of variance and two-tailed t-test. $\mathrm{P}<0.05$ was considered to indicate a statistically significant difference.

\section{Results}

Mast cells and active expression of chymase are present in hypertrophic scar tissues. To detect the existence of mast cells and mast cell chymase in hypertrophic scars, immunohistochemistry was employed. The results demonstrated that in hypertrophic scar tissues, the number of mast cells, identified by brown staining of membranes, was greater than that in normal skin tissues (Fig. 1A and B). In addition, chymase expression in hypertrophic scar tissues was higher than that in normal skin, as indicated by the higher number of brown particles in the cell cytoplasm (Fig. 1C and D). These results suggested that mast cells and active expression of chymase were present in hypertrophic scar tissues.
Mast cell chymase promotes the mRNA expression of TGF- $\beta 1$, angiotensin and type I and III collagen in hypertrophic scar fibroblasts in a time- and dose-dependent manner. To assess the effect of chymase on TGF- $\beta 1$, angiotensin, and type I and III collagen mRNA expression in hypertrophic scar fibroblasts, RT-qPCR was performed. The results demonstrated that treatment with various concentrations of chymase for 6,12 and $24 \mathrm{~h}$ increased TGF- $\beta 1 \mathrm{mRNA}$ expression compared with that in the control group, particularly treatment with $120 \mathrm{ng} / \mathrm{ml}$ chymase for $12 \mathrm{~h}$ (Fig. 2A). Similar results were obtained for angiotensin mRNA expression, particularly after treatment with 60 and $120 \mathrm{ng} / \mathrm{ml}$ chymase for $12 \mathrm{~h}$, and 15 and $30 \mathrm{ng} / \mathrm{ml}$ chymase for $24 \mathrm{~h}$ (Fig. 2B). Particularly after treatment with 60 and $120 \mathrm{ng} / \mathrm{ml}$ chymase for $12 \mathrm{~h}$, type I collagen mRNA expression was enhanced compared with that in the control cells (Fig. 2C). Type III collagen mRNA expression was increased after incubation with various chymase concentrations for 12 or $24 \mathrm{~h}$ (Fig. 2D). These results indicated that mast cell chymase promotes the mRNA expression of TGF- $\beta 1$, angiotensin, and type I and III collagen in hypertrophic scar fibroblasts in a time- and dose-dependent manner.

Treatment with $60 \mathrm{ng} / \mathrm{ml}$ mast cell chymase for $12 \mathrm{~h}$ upregulates TGF- $\beta 1, P$-Smad2/3, Smad4 and Smad7 protein expression in hypertrophic scar fibroblasts. To investigate how chymase affects TGF- $\beta 1$, Smad4 and Smad7 protein expression as well as $\mathrm{P}-\mathrm{Smad} 2 / 3$ levels, western blot analysis was performed. The results revealed that treatment with 60 or $120 \mathrm{ng} / \mathrm{ml}$ chymase for $12 \mathrm{~h}$ significantly enhanced TGF- $\beta 1$ protein expression compared with that in the control cells $(0 \mathrm{ng} / \mathrm{ml}$ chymase $)$ $(\mathrm{P}<0.05$; Fig. 3A). In addition, treatment with $60 \mathrm{ng} / \mathrm{ml}$ chymase for $12 \mathrm{~h}$ significantly increased P-Smad2/3 levels 
A
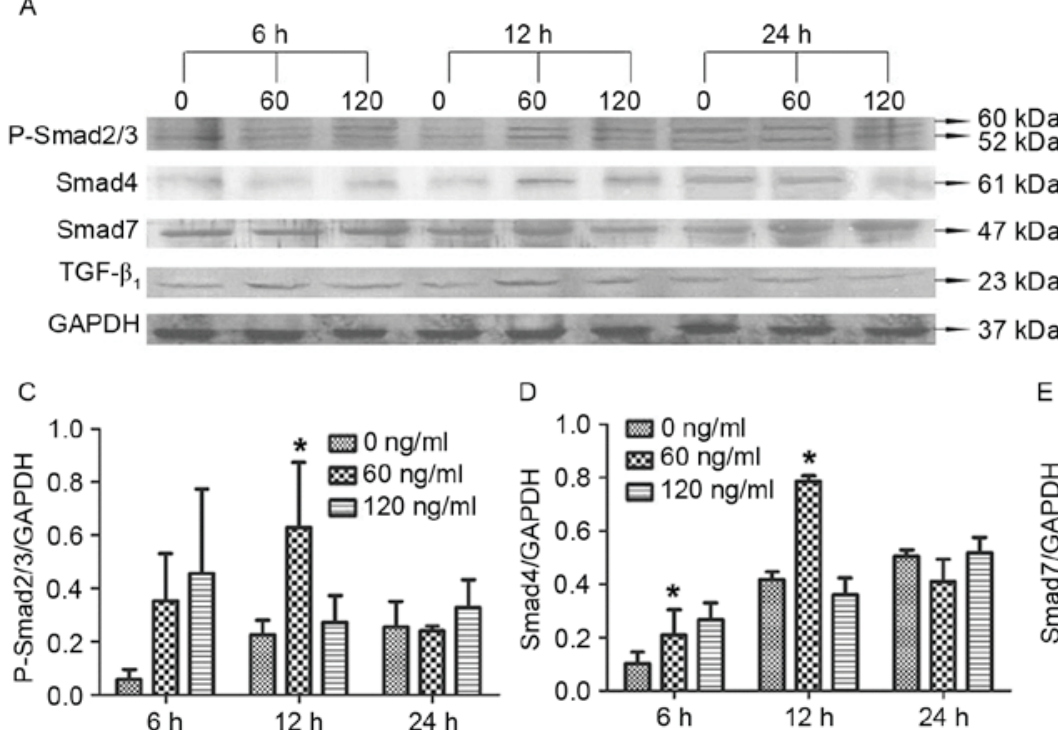

D
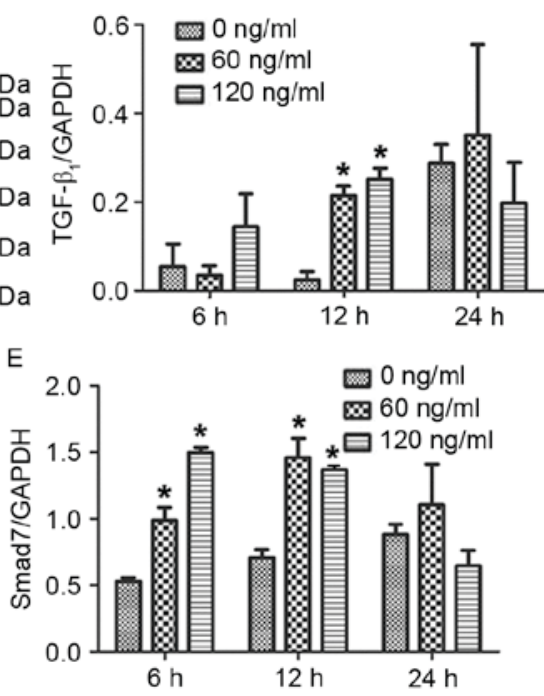

Figure 3. Effect of chymase on TGF- $\beta 1$, P-Smad2/3, Smad4 and Smad7 protein expression in hypertrophic scar fibroblasts. (A) Western blot image displaying TGF- $\beta 1$, P-Smad2/3, Smad4 and Smad7 protein levels after treatment with different concentrations of chymase (0, 60 or $120 \mathrm{ng} / \mathrm{ml})$ for 6,12 or $24 \mathrm{~h}$. Protein expression of (B) TGF- $\beta 1$, (C) P-Smad2/3, (D) Smad4 and (E) Smad7 normalized to GAPDH. All experiments were performed in triplicate. Values are expressed as the mean \pm standard deviation. ${ }^{*} \mathrm{P}<0.05$ compared with control $(0 \mathrm{ng} / \mathrm{ml}$ chymase). TGF, transforming growth factor; P-SMAD2/3, phosphorylated SMAD2/3

compared with those in the control cells $(\mathrm{P}<0.05$; Fig. 3B). Similarly, treatment with $60 \mathrm{ng} / \mathrm{ml}$ chymase for $12 \mathrm{~h}$ significantly increased Smad4 protein expression compared with that in the control $(\mathrm{P}<0.05$; Fig. $3 \mathrm{C})$. Furthermore, treatment with 60 or $120 \mathrm{ng} / \mathrm{ml}$ chymase for 6 or $12 \mathrm{~h}$ significantly elevated Smad 4 and Smad7 protein expression compared with that in the control ( $\mathrm{P}<0.05$; Fig. 3D and $\mathrm{E})$. The results suggested that treatment with $60 \mathrm{ng} / \mathrm{ml}$ mast cell chymase for $12 \mathrm{~h}$ led to an upregulation of TGF- $\beta 1, \mathrm{P}-\mathrm{Smad} 2 / 3, \operatorname{Smad} 4$ and Smad7 in hypertrophic scar fibroblasts.

\section{Discussion}

Hypertrophic scars are a type of skin tissue fibrosis mediated by inflammatory cells. In the formation stage of hypertrophic scars, an increase in the mast cell number is positively correlated with the severity of fibrosis (17). Compared with normal skin, active transmitters associated with mast cells are significantly increased, suggesting that mast cells and their transmitters are key factors for promoting hypertrophic scar formation (17). Chymase secreted by mast cells participates in the formation of skin matrix $(18,19)$. Castagnoli et al $(20)$ demonstrated that serine proteinase secreted by mast cells facilitates the proliferation of hypertrophic scar fibroblasts by eliminating contact inhibition, and promotes collagen synthesis, secretion and deposition in extracellular matrix. Mature mast cells are only present around blood vessels, or in the skin and mucus membranes, with specific phenotypes. CD117 (c-Kit) is an important receptor on the mast cell surface that regulates its function. In the present study, immunohistochemical staining demonstrated that the number of mast cells and the level of chymase activity in hypertrophic scars are significantly higher than those in normal skin, suggesting that mast cell chymase is present and active in hypertrophic scars.
Chymase has been demonstrated to induce the proliferation of cardiac fibroblasts, and to have important roles in the development of fibrosis in the lungs and heart via angiotensin II $(21,22)$. Angiotensin II is an important growth factor in the renin-angiotensin system. The renin-angiotensin system exists in the skin, and hypertrophic scar fibroblasts express angiotensin II receptors. The present study revealed that chymase upregulated angiotensin expression in fibroblasts isolated from hypertrophic scars. TGF- $\beta$ stimulates the differentiation and proliferation of fibroblasts by regulating the synthesis and deposition of extracellular matrix. It inhibits the production of collagenase and increases the production of collagenase inhibitors, finally leading to the sustained growth of hypertrophic scars. Overexpression of TGF- $\beta 1$ is a reason for the formation of hypertrophic scars $(23,24)$. Ghahary et al $(25)$ reported that the level of TGF- $\beta 1$ mRNA in hypertrophic scars is $61 \%$ higher than that in normal skin. Tredget et al (26) demonstrated that the mRNA and protein expression of TGF- $\beta 1$ in hypertrophic scars and their fibroblasts is significantly higher than that in normal skin and its cells. Similarly, the results of the present study demonstrated that mast cell chymase enhances the expression of TGF- $\beta 1$ in hypertrophic fibroblasts. Type I and III collagen is the main interstitial collagen that has important roles in the structural composition of extracellular matrix (26,27). Verhaegen et al (27) demonstrated that excessive deposition of collagen promotes the formation of hypertrophic scars. The results of the present study revealed that mast cell chymase (60 and $120 \mathrm{ng} / \mathrm{ml}$ ) increases the expression of type I and III collagen in hypertrophic scar fibroblasts. The present study also demonstrated that mast cell chymase enhances P-Smad2/3 as well as the protein expression of Smad4 and Smad7. The phosphorylation of Smad2/3 is a key step and marker in the Smad signaling pathway (28-30). Enhanced expression of Smad4 positively 
regulates the signaling pathway and activates downstream effector molecules $(29,30)$. Smad 7 is activated by TGF- $\beta$ and exerts its biological effects together with TGF- $\beta(29,30)$.

In conclusion, the present study demonstrated that mast cell chymase is present in hypertrophic scars with active expression. Mast cell chymase activates TGF- $\beta 1$ and facilitated the synthesis of collagen in hypertrophic scar fibroblasts in vitro. In addition, chymase activated the Smads signaling pathway and enhanced Smad protein expression. Therefore, it is concluded that mast cell chymase has important roles in the formation of hypertrophic scars through the TGF- $\beta 1 / \mathrm{Smads}$ signaling pathway. The present study provided a basis for research into the treatment of hypertrophic scars by inhibiting the activation and release of mast cell chymase in the future.

\section{Acknowledgements}

This work was supported by the National Natural Science Foundation of China (grant no. 81260291) and the Youth Science Foundation of the First Affiliated Hospital of Xinjiang Medical University (grant no. 2012QN02).

\section{References}

1. Beldon P: Abnormal scar formation in wound healing. Nurs Times 96: 44-45, 2000.

2. Shi Y and Massagé J: Mechanisms of TGF-beta signaling from cell membrance to the nucleus. Cell 113: 685-700, 2003.

3. Douaiher J, Succar J, Lancerotto L, Gurish MF, Orgill DP, Hamilton MJ, Krilis SA and Stevens RL: Development of mast cells and importance of their tryptase and chymase serine proteases in inflammation and wound healing. Adv Immunol 122 211-252, 2014

4. Zhao XY, Zhao LY, Zheng QS, Su JL, Guan H, Shang FJ, Niu XL, $\mathrm{He}$ YP and Lu XL: Chymase induces profibrotic response via transforming growth factor-beta $1 /$ Smad activation in rat cardiac fibroblasts. Mol Cell Biochem 310: 159-166, 2008.

5. Lindstedt KA, Wang Y, Shiota N, Saarinen J, Hyytiäinen M, Kokkonen JO, Keski-Oja J and Kovanen PT: Activation of paracrine TGF-betal signaling upon stimulation and degranulation of rat serosal mast cells: A novel function for chymase. FASEB J 15: 1377-1388, 2001 .

6. Muto T and Fukami H: Recent chymase inhibitors and their effects in in vivo models. IDrugs 5: 1141-1150, 2002.

7. Taipale J, Lohi J, Saarinen J, Kovanen PT and Keski-Oja J: Human mast cell chymase and leukocyte elastase release latent transforming growth factor-beta 1 from the extracellular matrix of cultured human epithelial and endothelial cells. J Biol Chem 270: 4689-4696, 1995.

8. Algermissen B, Hermes B, Feldmann-Boeddeker I, Bauer F and Henz BM: Mast cell chymase and tryptase during tissue turnover: Analysis on in vitro mitogenesis of fibroblasts and keratinocytes and alterations in cutaneous scars. Exp Dermatol 8: 193-198, 1999.

9. Fan SQ, Cai JL, Qin LY, Wang ZH, Liu ZZ and Sun ML: Effect of heparin on production of transforming growth factor (TGF)-beta1 and TGF-beta1 mRNA expression by human normal skin and hyperplastic scar fibroblasts. Ann Plast Surg 60: 299-305, 2008

10. Cowin AJ, Holmes TM, Brosnan P and Ferguson MW: Expression of TGF-beta and its receptors in murine fetal and adult dermal wounds. Eur J Dermatol 11: 424-431, 2001.

11. Walraven M, Gouverneur M, Middelkoop E, Beelen RH and Ulrich MM: Altered TGF- $\beta$ signaling in fetal fibroblasts: What is known about the underlying mechanisms? Wound Repair Regen 22: 3-13, 2014.
12. Blobe GC, Schiemann WP and Lodish HF: Role of transforming growth factor beta in human disease. N Engl J Med 342: $1350-1358,2000$

13. Yamamoto T, Hartmann K, Eckes B and Krieg T: Role of stem cell factor and monocyte chemoattrctant protein in the interaction between fibroblasts and mast cells in fibrosis. J Dermatol Sci 26: 106-111, 2001.

14. Yu H, Bock O, Bayat A, Ferguson MW and Mrowietz U: Decreased expression of inhibitory SMAD6 and SMAD7 in keloid scarring. J Plast Reconstr Aesthet Surg 59: 221-229, 2006.

15. Singer AJ and Clark RA: Cutaneous wound healing. N Engl J Med 341: 738-746, 1999.

16. Livak KJ and Schmittgen TD: Analysis of relative gene expression data using real-time quantitative PCR and the 2(-Delta Delta C(T)) method. Methods 25: 402-408, 2001.

17. Hermes B, Feldmann-Böddeker I, Welker P, Algermissen B, Steckelings MU, Grabbe J and Henz BM: Altered expression of mast cell chymase and tryptase and of c-Kit in human cutaneous scar tissue. J Invest Dermatol 114: 51-55, 2000.

18. Miller HR, Wright SH, Knight PA and Thornton EM: A novel function for transforming growth factor-beta1: Upregulation of the expression and the IgE-independent extracellular release of a mucosal mast cell granule-specific beta-chymase, mouse mast cell protease-1. Blood 93: 3473-3486, 1999.

19. Moyer KE, Saggers GC and Ehrlich HP: Mast cells promote fibroblast populated collagen lattice contraction through gap junction intercellular communication. Wound Repair Regen 12: 269-275, 2004

20. Castagnoli C, Stella M, Berthod C, Magliacani G and Richiardi PM: TNF production and hypertrophic scarring. Cell Immunol 147: 51-63, 1993.

21. Sakaguchi H, Takai S, Sakaguchi M, Sugiyama T, Ishihara T, Yao Y, Miyazaki M and Ikeda T: Chymase and angiotensin converting enzyme activities in a hamster model of glaucoma filtering surgery. Curr Eye Res 24: 325-331, 2002.

22. Younan G, Suber F, Xing W, Shi T, Kunori Y, Abrink M, Pejler G, Schlenner SM, Rodewald HR, Moore FD Jr, et al: The inflammatory response following an epidermal burn depends on the activities of mouse mast cell proteases 4 and 5. J Immunol 185: 7681-7690, 2010

23. Fan JM, Ng YY, Hill PA, Nikolic-Paterson DJ, Mu W, Atkins RC and Lan HY: Transforming growth factor-beta regulates tubular epithelial-myofibroblast transdiffetrntiation in vitro. Kideny Int 56: 1455-1467, 1999.

24. Willis BC and Borok Z: TGF-beta-induced EMT: Mechanisms and implications for fibrotic lung disease. Am J Physiol Lung Cell Mol Physiol 293: L525-L534, 2007.

25. Ghahary A, Shen YJ, Scott PG, Gong Y and Tredget EE: Enhanced expression of mRNA for transforming growth factor-beta, type I and type III procollagen in human postburn hypertrophic scar tissues. J Lab Clin Med 122: 465-473, 1993.

26. Tredget EE, Wang R, Shen Q, Scott PG and Ghahary A: Transforming growth factor-beta mRNA and protein in hypertrophic scar tissues and fibroblasts: Antagonism by IFN-alpha and IFN-gamma in vitro and in vivo. J Interferon Cytokine Res 20: 143-151, 2000.

27. Verhaegen PD, van Zuijlen PP, Pennings NM, van Marle J, Niessen FB, van der Horst CM and Middelkoop E: Differences in collagen architecture between keloid, hypertrophic scar, normotrophic scar, and normal skin: An objective histopathological analysis. Wound Repair Regen 17: 649-656, 2009.

28. Miyazono K, Maeda S and Imamura T: BMP receptor signaling: Transcriptional targets, regulation of signals, and signaling cross-talk. Cytokine Growth Factor Rev 16: 251-263, 2005.

29. Tao SJ and Sampath K: Alternative splicing of SMADs in differentiation and tissue homeostasis. Dev Growth Differ 52: 335-342, 2010.

30. Dabiri G, Campaner A, Morgan JR and Van De Water L: A TGF-beta1-dependent autocrine loop regulates the structure of focal adhesions in hypertrophic scar fibroblasts. J Invest Dermatol 126: 963-970, 2006. 